\title{
NON-EPILEPTIC MYOCLONUS AND MITOCHONDRIAL ENCEPHALOMYOPATHY
}

\author{
A. CUKIERT - F. G. M. NAYLOR* - H.B. SCAPOLAN * - M. M. VILELA * \\ F. S. ALOE* - J. O. SIFEERT*-ANA.M. TSANACLIS ***- MONICA HADDAD* \\ TERESA C. MACHADO*-MARY CARVALHO-ALEGRO***- J. A. LEVY**岀 \\ L. MARQUES-ASSIS *
}

SUMMARY - Two brothers presented to us with a progressive myoclonic syndrome with slight cerebellar symptoms. Neurological examination disclosed moderate cerebellax signs and pale optic discs; asymmetric, asynchronous and arhythmic myoclonus, an arthresthesic deficit and no muscular weakness, EEG background activity was moderately slow with no irritative discharges. CT was normal in both cases. Intermitent photic stirnulation increased the frequency of the myoclonic jerks, which became bilateral and synchronous, progressing to a generalized tonic-clonic seizure. EPs and MRI in one case were normal. Anticonvulsant drugs were ineffective. The diagnosis of mitochondrial encephalomyopathy was based on the finding, in muscle specimens, of thickened basement membranes with myofibrillary degeneration and nncreased number of mitochondria peripherally distributed and with a dense granular matrix and some vacuoles. The clinical and EEG data suggest a subcortical origin for this type of myoclonic syndrome.

\section{llioclonias nāu epilépticas e encefalomiopatia mitocondrial.}

RESUMO - Foram examinados dois irmâos portadores de uma sindrome mioclônica progressiva com discretos sintomas cerebelares. O exame neurológico mostrava sinaís cerebelares moderados e papilas pálidas; mioclonias assincronas, arritmicas e assimétricas, um déficit artrestésico e ausência de fraqueza muscular. A atividade de base do EEG era moderadamente lenta e sem atividade irritativa. A ' $\Gamma \mathrm{C}$ era normal $\mathrm{em}$ ambos os casos. A estimulação fótica intermitente aumentava a freqüência dos abalos mioclônicos que se tornavam bilaterais e sincronos, progredindo para uma crise tónico-cłonica generalizada. Potenciais evocados e $\mathrm{RMN}$ em um caso foram normais. Drogas anticonvulsivantes foram ineficazes no controle das mioclonias. $O$ diagnóstico de encefalomiopatia mitocondrial foi realizado através do achado em espécimes musculares de membranas basais espessadias, com degeneração miofibrilar e um número elevado de mitocondrias distribuídas perifericamente e com uma natriz densa, granular e com alguns vacúolos. Os achados clinicos e eletrográfícos sugerem uma origem subcortical para esta síndrome mioclónica.

Some cases of mitochondrial encephalomyopathy (MEM) may present the hallmarks for the diagnosis of a progressive myoclonic epilepsy (PME): a convulsive syndrome, myoclonus and mental deterioration. Likewise in other forms of PME, myoclonus can have a subcortical origin. Yet, each individual element of the aforementioned triad can also be originated in the cerebral cortex. In this paper two cases o. MLM are reported that had signs and symptoms of a PME in which the anatomophysiological basis of its clinical manifestations may primarily involve subcortical structures.

Faculty of Medicine, University of São Faulo (FRUSP) and Hospital das Clínicas, FMUSP: * Division of Neurology; ** Division of Functional Neurosurgery; *** Neurology Investigation Center. 


\section{MATEKIAL AND METHODS}

Two male brothers, GS and MS, aged 29 and 49 respectively, presenting a PME syndrome were submitted to a thorough clinical examination, prolonged EFG tracings, CAT, CSF analysis, EKG, hematologic and blood biochemistry exams.

Skin and muscle biopsies (biceps) were performed in both patients and were analised by optic and electron microscopy. GS was submitted to visual and somatosensory evoked potentials, a polisomnography, NMRI and EEG recordings with photostimulation under hypnosis and curarization in order to avoid myoclonic born electrographic artifacts.

\section{RESULTS}

GS, a 2y year-old countryman born in the State of Pernambuco first presented simple visual secondarily generalized tonic-clonic seizures at the age of eighteen. In the interictal periods there were arhythmic, asymmetric and asynchronous myoclonic jerks. 'Three other brothers suffered from the same illness, and one of them is described below. Mental deterioration was evident at a regular interview and the patient was not amenable to standard neuropsychological testing. Neurological examination showed no muscle weakness, a cerebellar syndrome with pastpointing, decomposition of movements of the four limbs, a slurred speach and a sensitive syndrome characterized by abnormal joint position sensation with normal vibration sense. Fundoscopic examinations displayed slightly pale papilae bilaterally. Low frequency, arhythmic, asynchronous and asymmetric myoclonus predominantly in the face and upper limbs muscles occurred with eyes open and became more severe with eyes closed or in dark places. At one occasion, a generalized tonic-clonic seizure was triggered by a three minute Iong dark-room exposure. EKG, CSF analysis and a hematological survey were normal. Prolonged EEG tracings disclosed only a few periods of delta and theta waves bilaterally over the frontal regions and no definite epileptic elements were recorded. Background activity was slightly slow and interspersed with muscle artifacts. Hyperventilation yielded no substantial EEG changes. Low frequency photostimulation $(1 \mathrm{~Hz}$ ) provoked a clear increase in both frequency and amplitude of the myoclonus, which at a certain point became bilateral, synchronous and symmetric, progressing to generalized tonic-clonic seizure. There was no EEG correlate to the myoclonic jerks. EFC recording under curarization and hypnosis showed periods of delta and theta waves over both frontal regions and no additional abnormal elements were recorded under low frequency photostimulation. A polisomnographic record showed a decreased REM sleep density. Visual evoked potentials showed a slight enhanced latency period. Somatosensory evoked potentials were normal. CT and MRI disclosed signs of a cortico-subcortical atrophy. Immunofluorescence studies of a skin biopsy were normal. Optic microscopy studies of muscle specimens were unable to demonstrate the presence of ragged-red fibers (RRF's). Electronic microspopy examination of muscle biopsies showed small areas of focal fibrosis and myofibrillary degeneration. Wavy and thickened sarcolemmae were frequent. Elongated mitochondria with a dense and heterogeneous matrix were seen in a great number as well as large agglomerates of mitochondria in a subsarcolemmal position (Figures 1 and 2).

MS, a 49 year-old countryman born in the State of Pernambuco presented asynchronous, arhythmic and asymmetric myoclonus since the age of fourteen. At the age of eighteen he noticed a progressive gait disturbance. Sporadic episodes of loss of consciousness (apparently generalized tonic-clonic seizures) were reported by the patient. At a regular interview mental deterioriation was evident and the patient was not suitable for neuropsychological testing. Neurologic examination showed normal muscle power, a cerebellar syndrome characterized by an ataxic gait, disarthric speech, past-pointing and movement decomposition in the four limbs. Abnormal point position with normal vibration sensations was noticed. Fundoscopic examination showed slightly atrophic papilae. Arhythmic, asynchronous and asymmetric myoclonus of small amplitude predominating in the upper limbs could be seen. Eyes closure did not alter myoclonus characteristics. CSF analysis and hematologic exams were reported normal. An EKG showing a sinusal bradychardia of $40 \mathrm{bpm}$ with a few supraventricular PVCs and anterior left halfblockade was recorded. Sorologic reactions for Chagas' disease were negative and Schistosoma mansoni eggs were found in the feces. EEG was normal but CT scanning showed signs of cortico-subcortical atrophy. Skin and muscle biopsy examinations under optic and electronic microscopy yielded findings similar to the first case (GS).

Both patients received, valproate, carbamazepine, phenytoin, barbiturates and benzodiazepines monotherapies with no improvement of the myoclonic jerks or epileptic syndrome. 

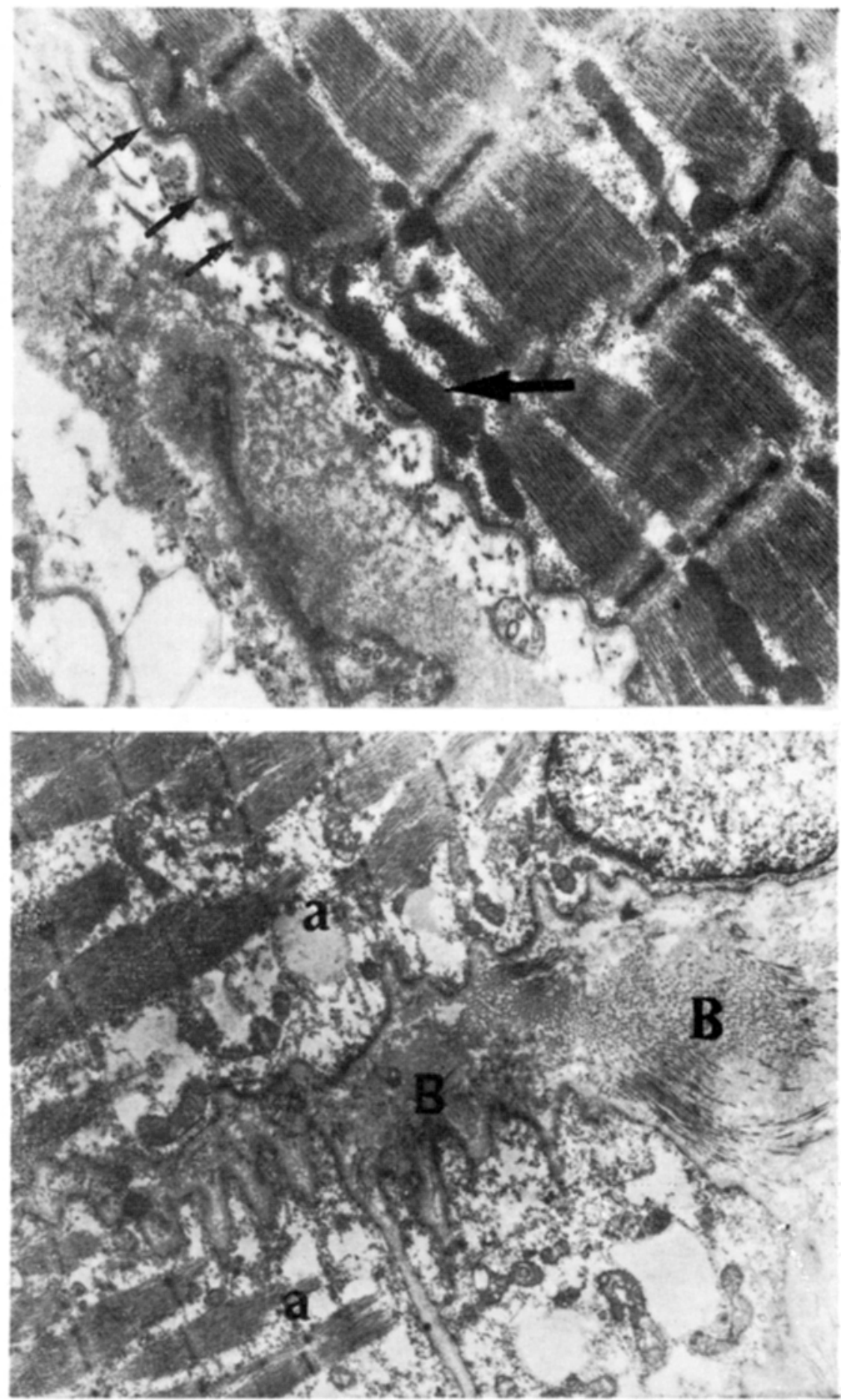

Fig. 1 - Patient GS. Above: photomicrograph shoving wavy cellular and basement membranes (small arrow); some mitochondria with a dense matrix could be seen among the myofibrils (big arrow) ( $\times 9500)$. Below: photomicrograph showing focal myofibrillary degeneration; some sarcomeres area destroyed (a) with some areas of fibrosis (B) ( $\times 4900)$. 

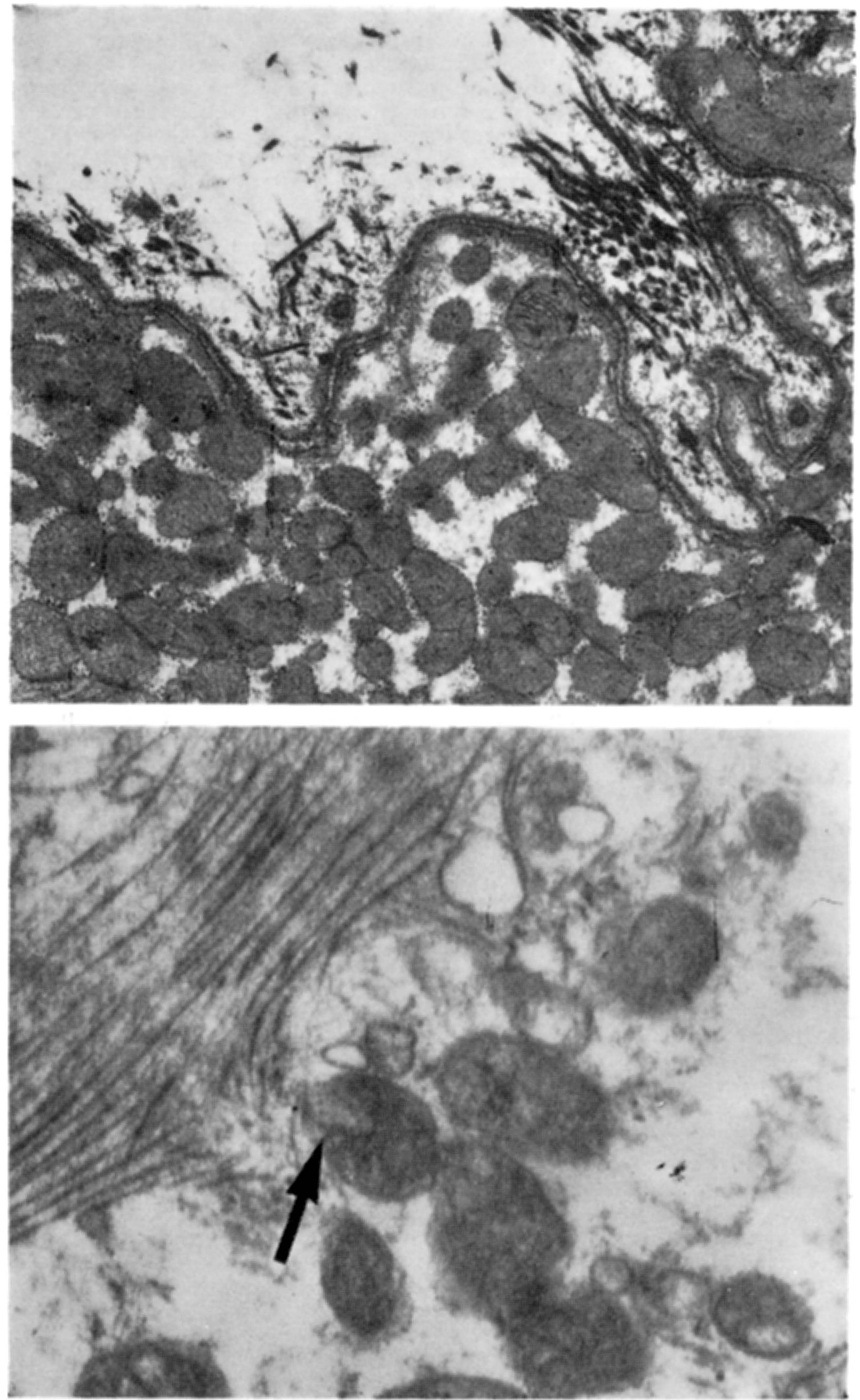

Fig. 2 - Patient GS. Above: photomicrograph showing a subsarcolemmal agglomerate of abnormal mitochondria; some of them have a dense matrix ( $\times 9500)$. Below: photomicrograph showing mitochondria with an irregular matrix, unorganized criptae and some vacuoles $(\times 28000)$. 


\section{COMMENTS}

The EEG findings in both cases suggest a subcortical origin of the myoclonic jerks in this form of MEM. The clinical progression of the seizure reported for case 1 suggests a subcortico-cortico-subcortical loop as the underlying anatomophysiological basis for this epileptic syndrome as opposed to the usual cortico-subcortico-cortical loop as seen in many non-progressive forms of epilepsy. About thirty cases of MEM presenting as a PME were so far reported and in many of them the EEG clearly showed diffuse epileptic abnormalities. In these cases previously reported, the EEG changes appear to relate to the epileptic syndrome but there was no EEG correlate for the myoclonic syndrome.

The definitive diagnosis of MEM is based on the findings of abnormal mitochondria mainly in muscle specimens. RRFs are frequently found in optic microscopy examination and one negative sample does not rule out completely the diagnosis of MEM. Yet, other samples from different muscles may yield positive results. in addition to that, the abscence of RRFs does not rule out the diagnosis of other forms of MEM. The most common histopathologic findings in $M E M$ correspond to a selective neuronal loss specially in the dentate cerebellar nucleus and olivary nucleus with simultaneous degeneration of the superior cerebellar peduncles and dorsal funiculli with disseminated cerebellar and brain stem gliosis $\mathbf{1 2 , 1 6}$.

PME-like MEM has been denominated MERRF (myoclonus epilepsy and ragged-red fibers). However, some controversy has arisen recently in the current literature since cases similar to ours with no RRFs have also been called MERRF 7 . The authors prefer to name the latter as MEM presenting as a PME with no RRFs. In both cases reported here no RRFs were observed. Additional muscle biopsies obtained from different muscles could have yielded different results. So far, no mitochondrial changes were recorded in CNS cells in cases of MEM. The actual difficulty to obtain adequate samples and different histopathologic responses of both CNS and other tissues may account for this failure. Furthermore, it is not possible so far to assure that CNS manifestations are caused by a nervous cell respiratory blockade. The search for specific biochemical mitochondrial defects has led to the demonstration of such abnormalities in at least three out of five distinct respiratory mitochondrial enzymatic complexes $3,11,15$. Nonetheless, it has not been possible to relate any specific biochemical deficits to a distinct clinical picture.

Many syndromes described in the past are now classified as MEMs. Ramsay-Hunt syndrome 2,8, Friedreich ataxia associated to convulsions 17,19 and Leigh syndrome 4,18 were found to show mitochondrial abnormalities. The cases reported by Ekbom 6 and May and White 10 as well as many others described as multisystem degeneration may represent distinct examples of MEMs 9 . Other MEMs as the MELAS (mitochondrial myopathy, encephalopathy, lactic acidosis and stroke like episodes) 13 possess a different clinical progression.

Due to the broad clinical spectrum of the MEMs 14 , these are very likely to be underdiagnosed in tile current practice. A more accurate classification of the specific phenotypes and their associated biochemical deficits will lead to a better understanding of these disorders.

\section{REFERENCES}

1. Berkovic SF, Andermann F, Carpenter S, Wolfe S - Progressive myoclonus epilepsies: specific causes and diagnosis. N Engl J Med 315:296, 1986.

2. Bird TD, Shaw $\mathrm{CM}$ - Progressive myoclonus epilepsy with dentatorubral degeneration: a clinicopathological study of the Ramsay-Hunt syndrome. $J$ Neurol Neurosurg Psychiat $41: 140,1978$.

3. Byrne E, Trounce I - Oxigen electrode studies with human skeletal muscle mitochondria in vitro: a reappraisal. J Neurol Sci $69: 319,1982$.

4. Crosby TW, Chou SM - 'Ragged-red' fibers in Leigh disease. Neurology 24:49, 1974.

5. DiMauro S, Bonilla E, Zeviani M, Nagakawa M, DeVivo D - Mitochondrial myopathies. Ann Neurol 17:521, 1985 .

6. Ekbom K - Hereditary ataxia, photomyoclonus, skeletal deformities and lipoma. Acta Neurol scand 51:393, 1975 .

7. Fukuhara N, Tokiguchi S, Shirakawa K, Tsubaki T - Myoclonus epilepsy associated with ragged red fibers (mitochondrilal abnormalities): disease entity or a syndrome? J Neurol Sci $47: 117,1980$. 
8. Hunt JR - Dyssinergia cerebellaris myoclonica: primary atrophy of the dentate system. A contribution to the pathology and symptomatology of the cerebellum. Brain $44: 490,1921$.

9. Karpati $G$, Carpenter S, Larbrisseau A, Lafontaine $R-$ The Kearns-Shy syndrome: a multisystem disease with mitochonarial abnormality demonstrated in skeletal muscle and skin. $J$ Neurol Sci 19:133, 1973.

10. May DL, White HFI - Familial myoclonus, cerebeliar ataxia and deafness. Arch Neurol 19:331, 1968.

11. Morgan-Hughes J A - Mitochondrial diseases. Trends in Neuroscience 9:15, 1986.

12. Nakano $T$, Sakai $H$, Amaro $N$, Yagishita $S$, Ito $Y$ - An autopsy case of degtenerative type of myoclonus epilepsy associated with Frjedreich's lataxia and mitochondrial myopathy. Brain and Nerve $34: 321,1982$.

13. Pavlakis SG, Phillips PC, DiMauro, S, DeVivo DC, Rowland LP - Mitochondrial myopathy, encephalopathy, lactic acidosis and stroke like episodes: a distinctive clinical syndrome. Ann Neurol 16:481, 1984 .

14. Petty KKFE, Harding AE, Morgan-Fughes JA — The clinical features of mitochondrial myopathy Brain 109:915, 1986.

15. Riggs JE, Schochet SS, Fakadej AV, Papadimitriou A, DiMauro S, Crosby TW, Gutmann L, Moxley RT - Mitochondrial encephalomyopathy with decreased succinate-cytochrome C reductase activity. Neurology $34: 48,1984$.

16. Sazak $\mathbf{H}$, Kuzuhara $\mathbf{S}$, Kanazawa I, Nlakinishi $\mathbf{T}$, Ogata $\mathbf{T}$ - Myoclonus, cerebellar disorder, neuropathy, mitochondrial myopathy and ACTH deficiency. Neurology 33:1288, 1983.

17. Smith NJ, Espir MLE, Mattrews WB - Familial myoclonic epilepsy with ataxia and neuropathy with additional features of Friedreich ataxia and peroneal muscular atrophy. Brain 101:461, 1978.

18. Walter GF, Brucher JM, Martin JJ, Centerick C, Pilz P, Freund M. .- Leigh's disease: several nosological entities with identical histopathological complex? Neuropathol Appl Neurobiol 12:95, 1986 .

19. ZiegIer DK, Van Speybroech NW, Seitz EF - Myoclonic epilepsia partialis continua and Friedreich ataxia. Arch Neurol $31: 908,1974$. 